\title{
Country Selection for International Expansion: TOPSIS Method Analysis
}

\author{
Assamoi Valerie Christian, Yabin Zhang, Coulibaly Kigbajah Salifou \\ School of Economics and Trade, Hunan University, Changsha, China \\ Email: assamoivale@yahoo.fr, yabinzhang@hnu.edu.cn,coolsalif25@yahoo.fr
}

Received 22 March 2016; accepted 26 April 2016; published 29 April 2016

Copyright (C) 2016 by authors and Scientific Research Publishing Inc.

This work is licensed under the Creative Commons Attribution International License (CC BY). http://creativecommons.org/licenses/by/4.0/

(c) (7) Open Access

\begin{abstract}
Using multi-criteria TOPSIS decision analysis, aimed at an optimal choice from a pool of alternatives between positive and negative ideal solutions respectively, subject to a relatively shorter geometric distance to the former solution, a step by step process is carried out to elaborate on how to successfully select a market for expansion. Dataset of 13 economic indicators covering a period from 2000 to 2013 has been used to evaluate the best suitable country among five African emerging markets for the expansion of an Ivorian company named FILTISAC. The results indicate that TOPSIS is a robust and efficient method that can be utilized in a multi-decision analysis process for country selection in view of foreign market expansion strategy. It is empirically determined that South Africa is the most suitable country for company expansion amongst those selected viz. Nigeria, Egypt, Morocco and Ghana.
\end{abstract}

\section{Keywords}

\section{Country Selection, Market Expansion, TOPSIS Multi-Criteria Model, Emerging Markets}

\section{Introduction}

Business is the biggest activity in the world today and has become more important for countries and companies. Companies have been expanding their activities overseas around the world with rapid globalization in order to take advantage of expanded markets and resources that exist across borders. Operating a company only at national levels separates it from the world market [1] and so it is important for most companies to go abroad. However, to enter in a specific market successfully and start up an economic activity remains a challenge to many firms.

When companies expand too quickly to take advantages and opportunities in emerging markets like Brazil, China or India, they risk venturing abroad before they are fully prepared to access these markets. It is clear that 
foreign expansion carries great opportunities, but there are obstacles that must be overcome before achieving a successful expansion. The expansion process of a company is a dynamic one and aims at the introduction of the company in foreign markets, economically and legally from those of the national business market.

Going abroad as a company is a risky decision that must not be taken lightly. According to [2] [3], entering new foreign markets demands a lot of organization and plans. It is important to recognize that countries are different on certain aspects such as their economic growth, their development, the market size, their market potential and so on. All these different aspects allow them to be more or less attractive for a firm to invest in. Taking into account all these aspects and cultural differences before making a decision on the country becomes one of the most difficult tasks. Foreign market selection is an important process but a daunting challenge for all companies and so firms need to pay careful attention before entering foreign markets [3] [4]. Many published studies focusing on the selection of foreign markets have shown that the most important factor for entering new markets is companies' knowledge about foreign markets [5]. Great knowledge of foreign market conditions strengthens the competence of the firm. Companies must do some market research and analysis such as the knowledge on the market, the availability of resources, and the strategies to be used when they decide to expand their activities into a foreign market. Another important aspect that needs to be taken seriously at the beginning of market expansion is the market environment. Market environments are undergoing significant changes [6].

This study uses the method of technique for order preference by similarity to ideal solution (TOPSIS) for selecting the suitable market. There are many applications of the method (TOPSIS) in different fields.

[7] developed techniques to avoid the conflicting preference alternative rankings and finally the method applied was the TOPSIS method. This method allowed him to give credibility to the choice function if any disagreement appeared between compromise solutions. In a numerical application, a customer wanted to purchase a family car and faced with the problem of choosing between eight automobiles, by using a sample of 8 family cars and 16 attributes, the preference ranking set showed that Toyota Corona was the best preference.

[8] conducted research on knowledge management in a company using the TOPSIS method to select the most accurate knowledge management factors. The study developed two criteria which were divided in six subcriteria to be evaluated and found that the most appropriate criterion was "personalization". This particular technique is decisive in the decision making process in a company, in which the technique plays a key role in the operation system for companies [9]. Implemented TOPSIS method to understand the supply chain management. Therefore, the position occupied by the TOPSIS model is crucial and decisive in the selection of multiple alternatives. By expanding to bank management, [10] suggested the use of TOPSIS method in the selection of the most appropriate location for a bank's branch. Location selection is one of the most important decision making process which requires to consider several criteria based on the mission and the strategy.

Recently, [11] developed in his study that making a decision in the process of developing and in the urbanization of new towns for sustainable development is most complicated. The fact that one area has to be chosen among several areas selected for the project, a multi criteria decision analysis is fundamental. Therefore, among the various techniques, Assad used TOPSIS, well known for its properties to extend the site selection in Iran. The site selection was based on five regions: Parand, Andishe, Hashtgerd and Pardis new towns. The study focused on three criteria and all of them divided into sub-criteria. The findings clearly showed that Parand was the optimal site location.

Thus, [12] used two types of multi criteria decision making techniques such as Simple Additive Weighting (SAW) which is also referred as weighted linear combination or scoring methods or weighted sum method; it is a simple and the most often used multi attribute decision technique and TOPSIS method. In his study, he found that TOPSIS provides the best option in decision making than SAW to select the best network to handover for target visitor networks. Also [13] conducted research to solve the evaluation problems of logistic risks in an incomplete information situation by using the TOPSIS method. So, the technique permitted to calculate the shortest distance to 2-tuple (in computer algorithms, dimensional matrix of $n$ elements) and the farthest distance to 2-tuple. These findings came to solve the emergency logistics risks.

All these literatures elucidate in this paper show how a variety of research fields have used this specific technique of TOPSIS except the field of international business. Therefore this study applies the TOPSIS method for the first time, to be the barometer of country selection for a company expansion.

To achieve this, a number of problems need to be addressed as follows: which strategies would the companies use to access an international market? In which country they could go firstly? Which method is the best to a quantitative method of foreign market analysis? What is a technique for order preference by similarity to ideal 
solution?

The purpose of this paper is to find a step by step process as to how to successfully select a market for expansion. In other words, it is to highlight market selection through TOPSIS method for more effectiveness and efficiency to enable company success in market expansion.

This work can be helpful for academic purpose and decision making, particularly those learning international business as a practical example of company's expansion showing how to go about selecting suitable foreign firms for expansion especially in African emerging markets. Results could provide new insight upon inquiries.

We organize the remainder of this article as follows. Section 2 sets out TOPSIS procedure. Then, section 3 describes the data collected for the study. Section 4 applies TOPSIS method in a case study: FILTISAC. Eventually, section 5 concludes.

\section{TOPSIS Approach}

TOPSIS (Technique for Order Preference by Similarity to Ideal Solution) is one of the multi-criteria decisionmaking (MCDM) methods [14]. This method evaluates the alternatives based on two rules: one is close to the ideal solution; the other is far away from negative ideal solution [15]. TOPSIS has been applied to many fields such as risk evaluation, performance evaluation, and suppliers' selection since it was proposed by [16].

In practice, TOPSIS has been successfully applied to solve selection/evaluation problems with a finite number of alternatives [17] because it is intuitive and easy to understand and implement.

In order to compute the TOPSIS method for selection problem, we first compute the normalized ratings, weighted normalized ratings, identifying positive-ideal and negative-ideal solutions, separation measures, similarities to positive-ideal solutions and lastly rank preference order.

To enable a clear understanding of the steps involved in the TOPSIS procedure to solve the country selection problem, the following steps were taken:

Step 1: Calculation of normalized ratings seeks to find the vector normalization denoted as $R_{i j}$ with $i=1, \cdots, m$ and $j=1, \cdots, n$ where $m$ and $n$ are respectively called alternatives and attributes. Therefore the function is defined as:

$$
R_{i j}=X_{i j}, \quad i=1, \cdots, m \text { and } j=1, \cdots, n .
$$

Sept 2: Weighted normalized ratings, this is a method to define the weights of each attributes and it is denoted as $V_{i j}$ and Equation (2) is written as:

$$
V_{i j}=W_{j} R_{i j}, \quad i=1, \cdots, m \text { and } j=1, \cdots, n .
$$

where $W_{j}$ is the weight of the attribute. It represents the relative importance among the attributes.

Step 3: Identify positive-ideal $\left(A^{*}\right)$ and negative-ideal $\left(A^{-}\right)$solutions, this step leads to determine the worst and the best alternative of preference. Thus the respective Equations (3) and (4) are:

$$
\begin{gathered}
A^{*}=\left\{V_{1}^{*}, V_{2}^{*}, \cdots, V_{j}^{*}, \cdots, V_{n}^{*}\right\} \\
A^{*}=\left\{\left(\max V_{i j} \mid j \in J_{1}\right),\left(\min V_{i j} \mid j \in J_{2}\right) \mid i=1,2, \cdots, m\right\} \\
A^{-}=\left\{V_{1}^{-}, V_{2}^{-}, \cdots, V_{j}^{-}, \cdots, V_{n}^{-}\right\} \\
A^{-}=\left\{\left(\min V_{i j} \mid j \in J_{1}\right),\left(\max V_{i j} \mid j \in J_{2}\right) \mid i=1,2, \cdots, m\right\}
\end{gathered}
$$

where $J_{1}$ is a set of larger-the-better-type and $J_{2}$ is a set of smaller-the-better-type. Both of them can be called benefit and cost attributes.

Step 4: Separation measures are a calculation between alternatives and that follows the mathematics formula called Euclidian distance. This separation is based on the previous step of TOPSIS method. This means that there are separations from the positive-ideal solution and the negative-ideal solution mentioned above, $A^{*}$ and $A^{-}$. Therefore the formulas are specified as:

$$
S_{i}^{*}=\sqrt{\sum_{j=1}^{n}\left(v_{i j}-v_{j}^{*}\right)^{2}}, i=1, \cdots, m
$$




$$
S_{i}^{-}=\sqrt{\sum_{j=1}^{n}\left(v_{i j}-v_{j}^{-}\right)^{2}}, i=1, \cdots, m .
$$

Step 5: Similarities to positive-ideal solution are applied to finalize the coefficient of rank preference order. The equation used to rank the alternatives is written as:

$$
C_{i}^{*}=\frac{S_{i}^{-}}{\left(S_{i}^{*}+S_{i}^{-}\right)}, i=1, \cdots, m, 0 \leq C_{i}^{*} \leq 1 .
$$

Step 6: Rank preference order is the step where based on the previous step, we choose the best alternative by maximizing $C_{i}^{*}$. By saying that, we choose the highest coefficient to be the top alternative of our study.

\section{Data Description}

This study applies TOPSIS method described above for a selected panel of five African emerging markets. The studied population samples were all African emerging markets .Due to the unavailability of data and economic potential some countries are excluded in the final sample. Thus we selected these five countries based on the geographical location to conduct the research. Data used in this research are extracted from various sources such as World Bank, Wolfram alpha, Economic freedom of the world 2014 and Geert-Hofstede cultural dimension.

We use various sources to collect data because of the difficulty to found the overall data in one source. There are sources where data on 13 years is not available. Some sources provide data on 13 years but only for one or two countries.

The dataset entails 13 variables for each country and covering a period from 2000 to 2013. We capture several factors expected to affect an economy's attractiveness for company to invest. Table 1 shows the indicators used in this study for the selection of a new market.

\section{Results and Discussion}

\subsection{Results}

In this part, we apply TOPSIS method to solving country selection problem for FILTISAC. FILTISAC is a company which manufactures bags made from the natural fiber, jute. In the beginning FILTISAC was created by IPS (WA) in 1965 to provide packaging for Cote d'Ivoire's coffee and cocoa exports. But now, FILTISAC diversifies its operations, moving into the manufacture of synthetic fiber packaging for the transportation of such products as cotton, rice, fertilizer, flour and cement. Continuing its expansion, FILTISAC began offering increasingly tailored packaging solutions and helped improve the safety and traceability of transported products.

To broaden its product range and increase its presence in the West African sub-region, FILTISAC created or acquired a number of subsidiaries: FASOPLAST in Burkina Faso (extrusion blow moulding), EMBALMALI in Mali (synthetic packaging), COFISAC (synthetic packaging) and FUMOA (metal drums and plastic packaging) in Senegal, to address the packaging needs in the West and Central Africa region with a firm strategy to modernize production facilities and boost sales.

We analyze the five emerging markets in Africa, such as Egypt, Morocco, Nigeria, Ghana, and South Africa.

Based on the first step of the TOPSIS procedure, Equation (1) established above is required to summarize the results in Table 2 as such.

The weighted normalized decision matrix is found using the Equation (2) and shown in Table 3.

Table 4 is the result of the formula specified in Equations (3) and (4). Along the same technique which follows all the formulae proposed in each step.

Separation measures from $A^{*}$ and $A^{-}$is computed by using Equations (5) and (6) respectively.

Equation (7) expresses all similarities to the positive-ideal solutions (Table 5).

Table 6 shows the final step results in the procedure of an efficient TOPSIS method and the preference order (ranked the countries) as follows:

$0.6120390>0.4561429>0.4361284>0.3835209>0.2824577$.

\subsection{Discussion}

According to the proxies used and the coefficients of each similarity denoted as $C_{i}^{*}$ the study demonstrates 
Table 1. Data description.

\begin{tabular}{|c|c|c|}
\hline Variables & Description & Sources \\
\hline $\mathrm{ECO} / \mathrm{FR}$ & $\begin{array}{l}\text { Economic freedom (ECO/FR): It affects every aspect of an individual's life. More } \\
\text { economic freedom improves well-being and leads to a higher quality of life. }\end{array}$ & $\begin{array}{l}\text { Economic freedom of the } \\
\text { World: } 2014\end{array}$ \\
\hline EDUC & $\begin{array}{l}\text { Education (EDUC): Percentage of school age children in secondary level has been used } \\
\text { in many studies as a measure of educational level. }\end{array}$ & World Bank \\
\hline GEO/DIS & $\begin{array}{l}\text { Geographical distance (GEO/DIS): It is often an important component of many forms of } \\
\text { spatial analyses in Business and Research. GEO/DIS measures the distance between } \\
\text { point locations. }\end{array}$ & Worlfram alpha \\
\hline MOBILE & $\begin{array}{l}\text { Mobile usage (MOBILE): Mobile cellular telephone subscriptions are subscriptions to a } \\
\text { public mobile telephone service using cellular technology, which provide access to the } \\
\text { public switched telephone network. Post-paid and prepaid subscriptions are included. }\end{array}$ & World Bank \\
\hline GDP & $\begin{array}{l}\text { Gross domestic Product: The gross domestic product (GDP) one of the primary } \\
\text { indicators used to gauge the health of a country's economy. It represents the total dollar } \\
\text { value of all goods and services produced over a specific time period. }\end{array}$ & World Bank \\
\hline IMP & $\begin{array}{l}\text { Imports are goods purchased from other countries. Importation is the entry of goods } \\
\text { from a place outside the territory. }\end{array}$ & World Bank \\
\hline \multirow[t]{2}{*}{ EXP } & $\begin{array}{l}\text { Export: Exporting is the act of producing goods or services in one country and selling or } \\
\text { trading them to another country. }\end{array}$ & World Bank \\
\hline & Hofstede's dimensions & $\begin{array}{l}\text { Geert Hofstede cultural } \\
\text { dimension }\end{array}$ \\
\hline PDI & $\begin{array}{l}\text { Power Distance (PDI): It is defined as the extent to which the less powerful members of } \\
\text { institutions and organizations within a country expect and accept that power is } \\
\text { distributed unequally. }\end{array}$ & $\begin{array}{l}\text { Geert Hofstede cultural } \\
\text { dimension }\end{array}$ \\
\hline IDV & $\begin{array}{l}\text { Individualism (IDV): The fundamental issue addressed by this dimension is the degree } \\
\text { of interdependence a society maintains among its members. }\end{array}$ & $\begin{array}{l}\text { Geert Hofstede cultural } \\
\text { dimension }\end{array}$ \\
\hline MAS & $\begin{array}{l}\text { Masculinity (MAS): A high score (masculine) on this dimension indicates that the } \\
\text { society will be driven by competition, achievement and success, with success being } \\
\text { defined by the winner/best in field-a value system that starts in school and continues } \\
\text { throughout organizational behavior. A low score (feminine) on the dimension means } \\
\text { that the dominant values in society are caring for others and quality of life. A feminine } \\
\text { society is one where quality of life is the sign of success and standing out from the } \\
\text { crowd is not admirable. }\end{array}$ & $\begin{array}{l}\text { Geert Hofstede cultural } \\
\text { dimension }\end{array}$ \\
\hline UAI & $\begin{array}{l}\text { Uncertainty avoidance (UAI): The dimension Uncertainty Avoidance has to do with the } \\
\text { way that a society deals with the fact that the future can never be known: should we try } \\
\text { to control the future or just let it happen? This ambiguity brings with it anxiety and } \\
\text { different cultures have learnt to deal with this anxiety in different ways. }\end{array}$ & $\begin{array}{l}\text { Geert Hofstede cultural } \\
\text { dimension }\end{array}$ \\
\hline PRA & $\begin{array}{l}\text { PAGMA: This dimension describes how every society has to maintain some links with } \\
\text { its own past while dealing with the challenges of the present and future, and societies } \\
\text { prioritize these two existential goals differently. }\end{array}$ & $\begin{array}{l}\text { Geert Hofstede cultural } \\
\text { dimension }\end{array}$ \\
\hline POP & $\begin{array}{l}\text { Population refers to a person with a job but did not exercise for different reasons, such } \\
\text { as maternity leave and the unemployed are also part of the workforce. }\end{array}$ & World Bank \\
\hline
\end{tabular}

Table 2. Results of computation of the normalized ratings.

\begin{tabular}{|c|c|c|c|c|c|c|c|c|c|c|c|c|c|}
\hline Country & ECO/FR & EDUC & GEO/DIS & MOBILE & GDP & POP & IMP & EXP & PDI & IDV & MAS & UAI & PRA \\
\hline Egypt & 0.44572 & 0.48027 & 0.62506 & 0.39068 & 0.33989 & 0.42295 & 0.34875 & 0.33074 & 0.44270 & 0.27793 & 0.38027 & 0.55637 & 0.17576 \\
\hline Morocco & 0.43288 & 0.43218 & 0.42248 & 0.52324 & 0.39101 & 0.17615 & 0.48825 & 0.448863 & 0.442709 & 0.51139 & 0.44788 & 0.47291 & 0.35153 \\
\hline Nigeria & 0.41977 & 0.21134 & 0.09895 & 0.23929 & 0.65895 & 0.83427 & 0.29597 & 0.50470 & 0.50595 & 0.33351 & 0.50703 & 0.38250 & 0.32642 \\
\hline Ghana & 0.45856 & 0.37080 & 0.05641 & 0.32022 & 0.49232 & 0.12725 & 0.64378 & 0.51329 & 0.50595 & 0.16675 & 0.33802 & 0.45205 & 0.10043 \\
\hline $\begin{array}{l}\text { South } \\
\text { Africa }\end{array}$ & 0.47653 & 0.63276 & 0.64639 & 0.64324 & 0.23196 & 0.27904 & 0.37137 & 0.41342 & 0.30989 & 0.72262 & 0.53238 & 0.34077 & 0.85372 \\
\hline Weights & 0.07692 & 0.07692 & 0.07692 & 0.07692 & 0.07692 & 0.07692 & 0.07692 & 0.07692 & 0.07692 & .07692 & 0.07692 & 0.07692 & 0.07692 \\
\hline
\end{tabular}


Table 3. Weighted normalized decision matrix.

\begin{tabular}{|c|c|c|c|c|c|c|c|c|c|c|c|c|c|}
\hline Country & ECO/FR & EDUC & GEO & MOBILE & GDP & POP & IMP & EXP & PDI & IDV & MAS & UAI & PRA \\
\hline Egypt & 0.03428 & 0.03694 & 0.04808 & 03005 & 0.02614 & 0.03253 & 0.02683 & 0.02544 & 0.03405 & 0.02137 & 0.02925 & 0.04279 & 0.01352 \\
\hline Morocco & 0.03329 & 0.03324 & 0.03249 & 0.04024 & 0.03007 & 0.01355 & .03756 & 0.03405 & 0.03405 & 0.03933 & 0.03445 & 0.03637 & 0.02704 \\
\hline Nigeria & 0.03229 & 0.01625 & 0.00761 & 0.01840 & 0.05068 & 0.06417 & .02277 & 0.02277 & 0.03882 & 0.03891 & 0.02565 & 0.02942 & 0.02510 \\
\hline Ghana & 0.03527 & 0.02852 & 0.00433 & 0.02463 & 0.03787 & 0.00978 & 0.04952 & 0.00394 & 0.03891 & 0.01282 & 0.02600 & 0.03477 & 0.00772 \\
\hline $\begin{array}{l}\text { South } \\
\text { Africa }\end{array}$ & 0.03665 & 0.04867 & 0.04977 & 0.04948 & 0.01784 & 0.02146 & 0.02857 & 0.03180 & 0.02383 & 0.05558 & 0.04095 & 0.02621 & 0.06567 \\
\hline Weights & 0.03428 & 0.03694 & 0.04808 & 0.03005 & 0.02614 & 0.0325 & 0.02683 & 0.02544 & 0.03405 & 0.02137 & 0.02925 & 0.04279 & 0.01352 \\
\hline
\end{tabular}

Table 4. Positive and ideal solution.

\begin{tabular}{|c|c|c|c|c|c|c|c|c|c|c|c|c|c|}
\hline$A$ & & & 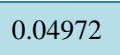 & 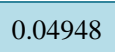 & & & & 48 & 91 & 58 & 95 & 79 & \\
\hline$A$ & & & & & & & & & & & & & \\
\hline
\end{tabular}

Table 5. Separation measures.

\begin{tabular}{|c|c|c|}
\hline Country & $A^{*}$ & $A^{-}$ \\
\hline Egypt & $9.25 e^{-03}$ & $3.58 e^{-03}$ \\
\hline Morocco & $5.65 e^{-03}$ & 0.003380 \\
\hline Nigeria & $7.25 e^{-03}$ & 0.005100 \\
\hline Ghana & $1.17 \mathrm{e}-02$ & 0.001813 \\
\hline South Africa & $3.90 \mathrm{e}^{-}-03$ & 0.009715 \\
\hline
\end{tabular}

Table 6. Similarities to positive-ideal solution and preference rank results.

\begin{tabular}{ccc}
\hline Country & $C^{*}$ & Rank \\
\hline Egypt & 0.3835209 & Fourth \\
Morocco & 0.4361284 & Third \\
Nigeria & 0.4561429 & Second \\
Ghana & 0.2824577 & Fifth \\
South Africa & 0.6120390 & First \\
\hline
\end{tabular}

that South Africa appears to be the best profile for the expansion of the company, then Nigeria, third Morocco, fourth Egypt and finally Ghana. The TOPSIS analysis showed that there is a gap between the first alternative (South Africa) which is the best one and the second alternative (Nigeria). This difference is about 0.16 and that is very important in terms of analysis because it shows that the performance of the South African market is much competitive as compared to the Nigerian market. In contrast the gap between the second and the third alternative is not significant. Therefore the competitiveness between Nigeria and Morocco is very tight. That means a thorough investigation could lead to withholding any investors decision in the process of expanding their market. Further, this study points out that, even though Nigeria is the largest economy in Africa it does not guarantee the highest returns to scale. With a lower purchasing power parity compared to South Africa, it may be one major reason why South Africa is a suitable market. This is the evidence which has been found in this study.

\section{Conclusions}

Effective market selection for expansion is a strategic decision that affects company performance. Mistakes can lead to financial loss of business and may also reduce the firm's advantages.

In this study, the multi criteria decision making (MCDM) based on the TOPSIS methods with quantitative 
data is applied to solve the problem as to how to go about in selecting countries for expansion. This method has been used as a powerful tool in market expansion analysis. A large data sample from 2000 to 2013 has been used to conduct an empirical investigation. The mathematical technique presented in the method is applied to find the best ratings and weights of criteria. The method requests certain steps for the calculation of coefficients for ranking each alternative. Following the proposed method, six steps can be undertaken to ensure the final decision. After various calculations based on different functions, an evaluation of these alternatives decisions' has been developed in the application of the TOPSIS method. Policy makers can rank the alternatives depending on the similarities of each coefficient.

Despite the difficulties in using TOPSIS, we noted no ambiguity in final results. Therefore the results of the analysis shows that the first ranking among the panel of five African countries based on their economic performance belongs to South Africa, second country is Nigeria, third country is Morocco, and fourth country is Egypt and then Ghana is the last country. We conclude this study by opining that the results meet our expectations. Nowadays South Africa is one of African countries which attract sizeable foreign investment and also the study indicates that TOPSIS can be used as a decision-support-model by decision makers for making effective market selection choice.

\section{References}

[1] Micheal, R.-C. and Iikka, A.-R. (2004) International Marketing. 7th Edition, Thomson South Western, Masion, Ohio.

[2] He, X. and Wei, Y. (2011) Linking Market Orientation to International Market Selection and International Performance. International Business Review, 20, 535-546. http://dx.doi.org/10.1016/j.ibusrev.2010.10.003

[3] O’farrell, P.N. and Wood, P.A. (1994) International Market Selection by Business Service Firms: Key Conceptual and Methodological Issues. International Business Review, 3, 243-261. http://dx.doi.org/10.1016/0969-5931(94)90004-3

[4] Papadopoulos, N. and Denis, J.E. (1988) Inventory Taxonomy and Assessment of Methods for International Market Selection. International Marketing Review, 5, 38-51. http://dx.doi.org/10.1108/eb008357

[5] Mullen, M.R. (2009) Foreign Market Analysis. Irish Marketing Review, 20, 47-56.

[6] Claver, E. and Quer, D. (2005) Choice of Market Entry Mode in China: The Influence of Firm Specific Factors. Journal of General Management, 30, 51-70.

[7] Kwangsun, Y. (1987) A Reconciliation among Discrete Compromise Solution. The Journal of Operation Research, 38, 277-286.

[8] Amin Zadeh, S. (2013) Developing TOPSIS Method Using Statistical Normalization for Selecting Knowledge Management Strategies. Journal of Industrial Engineering and Management, 6, 860-875.

[9] Pema, W.B. and Ruben, P. (2012) Application of AHP and TOPSIS Method for Supplier Selection Problem. Journal of Engineering, 2, 43-50.

[10] Nihan, C. (2009) A Decision Support Model for Bank Branch Location Selection. International Journal of Mechanical, 3, 18-23.

[11] Asad, A. (2014) Assessing Site Selection of New Towns Using TOPSIS Method under Entropy Logic: A Case Study: New Towns of Tehran Metropolitan Region (TMR). Journal of Environmental Management and Sustainable Development, 3, 48-74.

[12] Savitha, K. (2011) Trusted Network Selection Using Saw and TOPSIS Algorithms for Heterogeneous Wireless Networks. Journal of Networking and Internet Architecture, 1, 1108-1141.

[13] Li, W.H. (2012) The Research on the Emergency Logistics Risk Analysis with Incomplete Information. International Journal of Advancements in Computing Technology, 4, 304-310.

[14] Wei, S.X. and Zhou, X.Z (1998) Multi-Attribute Decision Making and Its Application in the c31. National Defence Industry Press, Beijing.

[15] Liang, Z., Yi, B., Yu, Z. and Wang, N. (2003) Spawning Areas and Early Development of Long Spiky-Head Carp (Luciobrama macrocephalus) in the Yangtze River and Pearl River, China. Hydrobiologia, 490, 169-179. http://dx.doi.org/10.1023/A:1023426909635

[16] Hwang, C.L. and Yoon, K. (1981) Multiple Attribute Decision Making: Methods and Applications. Springer-Verlag, New York. http://dx.doi.org/10.1007/978-3-642-48318-9

[17] Jee, D.-H. and Kang K.-J. (2000) A Method for Optimal Material Selection Aided with Decision Making Theory. Materials \& Design, 21, 199-206. http://dx.doi.org/10.1016/S0261-3069(99)00066-7 